\title{
Convergence on Policy Goals: Character EduCATION In EAST AsIa AND ENGLAND
}

\author{
James Arthur ${ }^{\mathrm{a}}$ \\ University of Birmingham
}

\begin{abstract}
The goal of character building in east Asian countries is often presented as a shared cultural construct and positioned within an east-west dichotomy. However, it is not at all clear that east Asian forms of character education are identifiable and distinct or that they always transcend national and cultural values. Jeynes (2008) has cautioned us to remember that cultural differences limit the extent to which we can learn lessons from another country, but how authoritative is this caution? The English Secretary of State for Education, Nicky Morgan, announced in December 2014 that she intended to secure England's place as a global leader by expanding the nation's provision and evidence base for character education. In this context, this article asks whether England shares any commonalities in the so-called east-west dichotomy on character education - are they mutually exclusive or are they compatible. Is there a west-individual view and an east - collective view? Is the character education movement in east Asia more of an ideological and political movement? As the British government looks for policy solutions to new and challenging problems, including character education, what answers can it find from abroad? What can it learn, borrow or pinch from these east Asian countries and is there a convergence on policy goals for character education within and across these countries? The paper is based on the work (translated) of prominent east Asian academics and builds on the author's personal interface with officials in the Ministry of Education in Japan and Singapore as well as meetings and conferences with numerous academics in universities across east Asian countries to address these questions.
\end{abstract}

Keywords: character, international comparisons, values, morals and schooling

\section{Introduction}

Character education in east Asian schools is experiencing a remarkable revival and re-emphasis. The purpose of education, as expressed through government legislation and regulations, in China, Vietnam, Taiwan, Singapore, South Korea and Japan has traditionally been explicitly linked to the building of character. Most of these countries are near the top of the Organization for Economic Development and Co-operation/Programme for International Student Assessment (OEDC/PISA) international league tables for academic attainment. It should be recognised that there is little or no research evidence that demonstrates a causal relationship between these examination results and character education. Consequently, this paper does not argue that England should adopt character education on the basis of east Asian success in PISA league tables. In recent years each of these east Asian governments has shown new and sometimes intense interest in looking at how to refresh and operationalise character education in schools. Each of these countries has either introduced new goals for character education or is currently planning a new curriculum in the next three years. Parental and societal concern about the behaviour of students is a factor fuelling the move to revitalise character education. On a broader level, what is happening is perhaps symptomatic of the vacuum of meaning engendered by consumerism and materialism, the symptoms of which these governments are recognising without necessarily understanding the full range of causes. English education has been reluctant to adopt policies on character education from east Asian countries. This reluctance

a Correspondence can be directed to: J.Arthur@bham.ac.uk 
may be due to cultural differences between England and east Asian systems of education. In the specific case of Japan, Traiger (1996) argues that the cultural differences are an 'unsurmountable barrier' to transfer of policy. This 'unsurmountable barrier' view feeds the notion that there is a basic dichotomy in modes of life and thought between England and countries in east Asia.

The notion that so-called 'cultural differences' between countries makes borrowing of educational ideas impossible seems fundamentally implausible. If it were true, Japan and Singapore would have been unable to set up a modern mass schooling system in imitation of western countries in the late nineteenth century, or borrow anything else from these countries in the hundred years since then; whereas, in fact, Asian countries have imported many practices and ideas from the west from sports to the ideas of Pestalozzi and Dewey. Such practices have been adapted to local context, which is normal in any borrowing process at any level, including within what is supposedly the same 'culture' or similar 'cultures'. Globalisation and the importance of looking 'elsewhere' have been valuable policy strategies for moderating educational reforms in these east Asian countries, which further helps explain the issue of convergence of policy goals. Few countries are hermetically sealed in regard to their educational systems as they engage in the international traffic of educational ideas and practices.

There has also been a growing recognition that an overly competitive schooling leads neither to happiness nor necessarily to economic dynamism. It is often argued that east Asian education systems are characterised by various degrees of rote memorisation, incessant testing, onerous homework, cram schools, private tutorial sessions and endless hours of effort that can start at 7am and end at 10pm. However, Cave (2007) reminds us that in the study of school mathematics, 'rote memorization' is more characteristic of mathematics teaching in England than in Japan and that in England, 'incessant testing' is increasingly becoming the norm. Starr (2012) argues that east Asian school systems teach the kind of factual knowledge that can be easily tested in comparative surveys and that this knowledge-based learning method may be less sophisticated and original as a result. There is also increasing recognition of little correlation between OCED/PISA league table results and success in later life. Nevertheless, all of these east Asian countries are marked by centralised control, prescriptive curricula, official textbooks, teachers as civil servants, educating for nation building and a degree of State paternalism.

Character education policy is usually a reflection of the prevalent values of a particular political context or jurisdiction. National cultural traditions are a major determinant and influence on education systems and therefore these systems are to a degree localised and culturally relative. East Asian societies have generally, at the level of goals, converged on similarly stated purposes for character education. There is a similarity of rhetoric, issues, and justifications for character education policies in many east Asian countries which are arrived at without any direct political link between them. These countries, it could be argued, have a comparable social-cultural formation in norms, values, beliefs and traditions which have combined to produce broadly comparable policy goals for character education. It is sometimes claimed that the guiding philosophy and discourse for these similarities in policy is derived in part from Confucian educational ideals and heritage with the emphasis on discipline, respect and humility (see Cen and Jun, 2014; Chou, Tu and Huang 2013; Starr, 2012; and Tu, 1996). Confucianism is most closely associated with Chinese societies and is about how people treat one another as well as how they behave individually. It is not a religion, but a system of moral, social and political philosophy. It is a system of thought centred on the Confucian theory of ren. This encompasses feelings of love and empathy and rests on the idea that if you want to be successful you must first help others to be successful. It sets standards for civility and appropriate behaviour and the main goal is the cultivation of character. However, one should be cautious in applying Confucian ideas too widely in east Asian societies as it is easy to exaggerate and over-generalise its influence. There are also other influences. Singapore, for example, is a distinctly pluralistic society and has more of a 'meritocracy' orientation. Nevertheless, some of the east Asian countries examined in this paper could be identified as what Starr (2012, p.17) calls 'Confucian heritage cultures'. 
There is, however, much agreement on broad aims for character education, but considerable variation in the political operation and processes of character education, resulting in divergence of content, practices, teaching approaches and assessment within these different jurisdictions. As in England, east Asian societies are largely seen as marked by competitive, data-driven standardised public school examinations and many believe that such systems have had a detrimental effect on attempts at character building in students. The renewed focus on character education is intended to counterbalance the perceived materialistic and selfish tendencies generated by exclusive focus on academic success in which a student's worth is judged solely by their academic attainment as measured in public examinations. Kristjánsson (2015) argues that in order to be truly successful, any programme of character education needs to satisfy four criteria. It must: (1) align with public perceptions and speak to the dominant anxieties and vulnerabilities of the given context; (2) meet with a relatively broad political consensus and attract political interest, ideally be both on the political 'left' and 'right'; (3) be underpinned by a respectable philosophical theory, providing it with a stable methodological, epistemological and moral basis; and (4) be supported by a plausible psychological theory, explaining how the ideals of the educational theory fit into actual human psychology and are generally attainable. Few, if any, of these criteria have been met in east Asian countries or even in England.

\section{Theoretical Approaches}

But why should national governments legislate for and promote virtue in their school systems? Why is it assumed that there ought to be a role for governments to improve the moral character of people? These questions invite normative justification for any State intervention in the school curriculum. In east Asia there is a diverse range of philosophical and religious approaches underpinning educational thinking, including Confucianism, Taoism, Buddhism, Maoism and Christianity. It must be recognised that a sense of religious identity exerts much influence on the common moral understanding of Asian people, but this article will restrict itself to the more philosophical elements of this moral understanding. In the west the focus is almost exclusively on western philosophical traditions, but there has been over the last century an enormous amount of interaction between eastern and western thought. Hence, to categorise the west as simply concerned to promote individualism and open debate and the east as predominantly concerned with collective values and social harmony would be misleading. All political states make demands on the school curriculum and schools naturally aim to define policies made by their locally elected politicians. However, a general definition of character education for east or west might be the acquisition and strengthening of virtues that sustain a well-rounded life. Character education is an umbrella-term for all explicit and implicit educational activities that help young people develop positive personal traits called virtues (see Arthur, 2003). On this view, schools should aim to develop confident students who are effective contributors to society, successful learners and responsible citizens. Students should be encouraged to develop a commitment to serving others, which is an essential manifestation of good character in action.

In the west Aristotle has been a major influence on both understanding political association and the character formation of citizens. Aristotle's Politics, in books 7-8 (see Lord, 2013), teaches that the end or purpose of the state is the highest good of citizens - in other words, a life of virtue. The aim of the state is to help shape the good life of its citizens. Mclntyre (1999, pp.128-129) following Aristotle, but with a culturally constructed understanding of virtue, views the state as concerned to foster citizenship and draws on the Aristotelian tradition as a basis for the development of character. Following this, the present paper also uses this Aristotelian theoretical approach to explore the possibility of east-west convergence on character education policy. In the west, moral theory has drawn on Kantian ethics, utilitarianism and virtue theory and each has their critics (see Doris 2002; Brandt 1992; and McIntyre, 1967). However, Aristotle's Ethics, in book 10 chapter 9 (see Broadie and Rowe, 2002) which effectively advocates moral education through the development of virtues, has elements in common with east Asian philosophical approaches to character formation. 
For example, Aristotle believed in a balanced collectivism and sought a life of positive association for all citizens and this sits well with the Asian aim of social harmony. However, Aristotle believed that the individual must not be entirely subordinate to the state. He emphasised the role of the family with the family seen as prior to the state. Nevertheless, he did believe that the state had a role to play in prohibiting unacceptable public behaviour while allowing considerable freedom to the individual. While Asian values are not Aristotelian in origin, however, there are similarities that might encourage connections, but Aristotle, we need to remember, was less collectivist than Asian values appear to be. To be sure, this would look different in China - where the government issues explicit moral guidance to citizens - from Japan where the individual has a greater degree of independence from state direction.

While Aristotle believed that every society is established for the sake of some good, Hunter $(2001$, p.228) has noted that politicians and civil servants are incapable of setting moral standards for character education. Liberal political theory in the west has also traditionally held that government has no business setting moral standards for the public. When a government or state prescribes a rigid curriculum for character education this might encourage dispositions of respect, responsibility and self-discipline, but might also foster submission, conformity and docility in citizens. On a liberal view, the virtues that form character should be freely chosen by citizens as desirable for their own sake. It is only through such freedom that truly virtuous citizens might be developed. Still, McIntyre (2013, p.11) believes that those who lack virtuous character do not make good citizens.

\section{English Character Education}

English education traditionally saw the purpose of education as character building and this was the explicit aim of the Department for Education (DfE) until just after the Second World War (Arthur 2003, pp.20-21). The purposes of east Asian national character education programmes are similar to what Nicky Morgan, (former) Secretary of State for Education in England, articulated at the Sunday Times Festival of Education in July 2015 when she said that 'building a strong character and a sense of moral purpose is the responsibility we have toward our children, our society, our nation'. This might well be echoed by any Minister of Education in east Asia. Today, England's education system is marked by detailed standards, accountability and test scores for league tables that may not be the most fertile environment for any new emphasis on character education. There is also the suspicion in psychological circles about the very idea of character education and efforts at such education are typically designed apart from the best available psychological evidence.

The English DfE has borrowed ideas from east Asian countries to shape policies in English schools, though there are few clear cut examples of 'hard' copying of policies from east Asia. Even the emphasis on traditional didactic approaches to teaching and learning, some of which have been borrowed from the east and applied in England by Michael Gove, the former Secretary of State for Education, has often been more rhetoric than reality in practice. Certainly, there are ideological and cultural incompatibilities which inhibit any straight transfer of policies - a point recognised by the reports of Michael Barber and McKinsey justifying the reform agenda in England (see Barber, 2012). Greater emphasis on broader educational values and practices rather than concrete polices per se is arguably what is required. However, the DfE rhetoric consistently links attainment to character skills such as resilience and grit. In contrast to east Asian educational systems, English education has in recent times aimed to be child-centred and individualistic in approach, but it is not clear that it has always realised these goals in practice. Children are encouraged to define and pursue their own goals in life and become autonomous thinkers and citizens. The intention is to maximise freedom and this is supported by a diversity of approaches in western educational psychology. Does this result in selfish individuals? Individuality cannot develop from a vacuum insofar as it needs a social atmosphere. In 1999, a specific statement of the aims and purposes of the English education system was published by the government as a preamble to the National Curriculum which included a 
Statement drawn from the 1996 National Forum for Values in Education and the Community (Arthur 2005, p.239f). This Statement emphasises both social and moral values.

The emphasis in English government circles over the last few years has been to emphasise resilience and grit, borrowing language from the US, and linking this to increased academic attainment and employability. So far there have been no government guidelines on what character education actually means, though it has become one of the five aims of the DfE and there is a minister responsible for introducing it and he is aided by a special character unit of civil servants. What lessons can England learn from east Asian countries? In east Asian countries the primary agency in the spreading, dispersion and dissemination of character building policies and practices is the state and its civil servants. State legislation, guidelines and regulations initiate policy changes which are normally prescribed for education. Such prescriptions are couched in high idealistic terms and issued from governments that may or may not be democratic, but have a strong dominant party system, or be authoritarian in the form of communist dictatorship - or even exhibit soft authoritarian tendencies that are not on the liberal western democratic model. In all these east Asian models of government the family, community and ultimately the nation are often seen as prior to the individual and there is frequently a fusion of the state, the leading political party and the bureaucracy making for stronger direction in education policy. A short review of each of these east Asian nations may serve as an introduction to their current character education provision. Three categories are outlined: quasi collectivist, quasi paternalistic and quasi authoritarian; but we see elements of all three at work in almost all east Asian societies.

\section{Quasi Collectivist Character Education}

The Japanese public senses a general decline of morality among the young evidenced by increasing levels of school absenteeism, violence, suicide and bullying. In this connection Ryan et. al (2011, p.17) argues that human behaviour is a function of both character and culture - shared values, group expectations, tradition that call forth either the best or the worst in our character. Takayama and Apple (2008, p.297) argue that the perceived Japanese 'crisis' is the reflection of a conservative discourse of tradition, order, patriotism and discipline which has formerly had the support of the Japanese people. Returning traditional moral education to schools has been a goal of Japanese conservatives since the Second World War. Green (2000) also indicates that Japanese education has reached a crisis point and, despite having one of the highest literacy rates in the world, it often looks to England for a reform agenda. The current 2006 Fundamental Law on Japanese Education, which is still seen in Japan as controversial and contested, refers to character in three places. First, in the introduction, it speaks of the purpose of education as the 'perfection of character'. Second, in paragraph three, it says that schools and teachers must 'polish the character' of their students. Third, in paragraph eleven, it says that moral education is 'the foundation of character' in schools. While the importance of character is already recognised, the revision of the National Curriculum in Japan is reviewing how to ensure that character education is implemented in every school. Moral education is already compulsory in Japanese schools, but its practice and quality varies. The Ministry of Education believes that there has been a failure to determine what moral education ought to be in the classroom. To this end there is a unit in the Ministry preparing new content for moral education for introduction in 2018 (primary schools) and 2019 (secondary schools). In a Wall Street Journal $\left(27^{\text {th }}\right.$ December 2015$)$ poll, $83 \%$ of parents in Japan agree that moral education should continue to be taught as a school subject, but only $22 \%$ of Japanese teachers believe it should be taught as a specific subject. Nevertheless, civil servants, teachers and academics are drawing up the curriculum for a special course in moral education.

Many Japanese academics see moral education as a field, rather than a school subject because it covers a wider area and is the responsibility of all teachers. Japan has decided to follow Singapore, China and South Korea in introducing a specific timetabled place in the school curriculum for moral and character education. The proposal is designed to give the subject greater status, but also involves 
more state control. This means that designated teachers need to be trained to teach this new subject and new textbooks be produced. No one in Japan would deny that some kind of character education is necessary in schools, but the term 'moral education' has become more ambiguous in academic circles with suspicions that the militaristic moral education of pre-war Japan with its imperialist goals, may engender new ultra-nationalism. It has also been argued that character building activities in Japan lead to high degrees of social conformity at odds with independence and autonomy in Japanese school students (see Otsu, 2000; Shields, 1998; and Jansen, 1957). Cave (2001, p.187; and 2007, pp.16-17) has carried out extensive research on 'individuality' in Japanese education and highlights the Japanese government's educational reforms in the 1990's designed to encourage creativity with the policy slogan 'stress on individuality'. While recognising that there was much ambiguity regarding 'individuality', he concluded that there was significant progress in providing some new freedom for teachers and encouraging 'self-directed learning'.

Justice, taken from Kojien, justice is defined as 'the right way to secure a good life' and 'individual virtue leading one to take the right action, for example, in distributing social goods'. This sits well with Aristotle's idea of justice as an acquired disposition to promote the common good, though Aristotle insists that such just agency should be voluntary. Japanese students tend to be well motivated and learn to be polite by required socialising with their fellow students. Notions of obligation and duty are communicated in the web of commitments to others in the Japanese terms giri and on. Both terms imply a strong sense of being embedded in a community where responding to the demands made by communal obligation has priority over individual desires. Thus, the kind of character education promoted is quasi-collectivist or communitarian in style and relies to some degree on the cultural homogeneity of the society. Some Confucian thought is invoked in Japanese character education, but there are also Buddhist, Shinto and even Christian influences (Luhmer 1990, p.172). The most important Confucian influence is the emphasis on interpersonal relations and the promotion of humility. The purpose of voluntary after-school clubs in Japan (Bukatsudo) is to help socialise Japanese youth as 'part of the group' (see Cave 2004, p.384) by emphasising participation, habit, repetition, routine, ritual, order, shared responsibility and discipline. Such clubs are run by teachers and involve sport, art and music, but generally discourage competition between students in favour of self-improvement, good manners and getting on with others. These clubs, influenced by English public school ethos of the nineteenth century, emphasise cheering others on so that everyone contributes to success. Such clubs are often compulsory, begin at the end of the school day and last for two hours up to six times a week. Some have suggested that these are vestiges of a previous 'militarised character training', others that they are about engendering obligations to the community and the promotion of the common good. There is still a strong consensus in Japanese society in favour of schools as agents of social stability and cultural preservation.

Japanese character education is understood as occurring via the ethos of schools as well as through the various student practices within them. So, for example, there is the culture of senior (senpai) and junior (kohai) whereby students learn good habits and behaviour from mentoring by seniors. It is a kind of apprenticeship programme and stresses role-modelling and imitation of behaviour. Another example is the practice of Hansei which requires each student to keep a reflective diary of all their daily activities and behaviour which the teacher reviews and comments on to aid improvement. During lunch hour, students take turns to serve food to class members and the teacher and all eat together in their class; there is often no cafeteria or dining hall in Japanese schools. Japanese schools generally have no cleaners since students are required to clean the whole school, including the school play-ground at the end of each day. Such practices are designed to socialise and build the characters of students as well as to encourage co-operation and responsibility for each other. The role of mothers in Japan is and has been to prepare lunch boxes for their children, supervise their substantial homework and encourage their desire to learn. But do such practices mould uniformity? It is perhaps important to distinguish between formal and informal moral/character education insofar as Japan emphasises both types. Informal moral and character education is intended to socialise children in more generally acceptable conduct and the 
formal element takes the form of one hour a week of explicit 'moral education' (dotoku) across the nine years of compulsory education.

\section{Quasi Paternalistic Character Education}

In Korea, a government report 'The agenda of education reform for the establishment of New Educational System' published in 2009 by the Ministry of Education, Science and Technology spoke about the need for the development of 'sound moral character' and the 'development of virtues involved in positive human relationships', as well as of preparing young people to make good ethical decisions in their lives. The three specific stated goals of character education are: understanding oneself, caring for and respecting others, and cultivating the ability to co-operate with others. Filial piety, another Confucian ideal, is emphasised and involves learning how to demonstrate respect for parents, grandparents and elders in the community. Co-operation and sharing are important, as well as developing a sense of balance and order. The intention is to empower students for responsible decisions that are ethical and socially acceptable. Previously students took the purpose of ethics or moral education classes to be simply about memorising information. However, the new government report seems to be prescribing what it believes students need; that the state becomes responsible for your character and in so doing strengthens its own hand over the individual.

Character education in South Korea is associated with strong government and with an anticommunist stand (Suh 1988, p.93). What the South Korean government calls the 'Character Education Promotion Act' was passed in January 2015 in the National Assembly. 'Creativity and character education' was the key education slogan of President Park in the presidential election campaign. But, until the year 2015, there has been no consensus about the meaning of character education. The Act offers an official definition of character (building) education. The Act envisages a national character education committee, the addition of relevant curricular units in schools, and new teacher education courses. According to this Act, all Korean schools (from kindergartens to high schools) will be required to teach students how to develop 'humane character and capabilities'. The definition of character education refers to teaching students how to 'develop the mentality and attitude necessary for living with others, and in nature. [and]...key values include etiquette, filial duty, generosity, cooperation, communication and responsibility'. Under the current examination focused curriculum, teachers fear that the teaching-to-the-test educational culture will produce another layer of administrative and evaluative ritual of curricular and instructional practices in local schools. Many teachers fear that the school culture of teaching to the new Korean SAT tests will simply mask character education (Lee, 2013 and Lee, 2001). The South Korean system also reflects some of the socialising practices in Japanese schools, such as eating with classmates and after school clubs.

Singapore has the highest percentage of separate ethnic groups and is more pluralistic than other east Asian societies. Character education, which is compulsory in Singapore schools needs to be understood as occurring within an evolving political and social framework that emphasises social integration and consensus. Habits and attitudes for a civic culture have not always been present in Singapore's schools (Kam and Gopinathan, 1999), but schools continue to play a major role in inculcating Singaporean values. Character, civic and moral education now play a major role in schools, emphasising honesty, commitment to excellence, teamwork, discipline, loyalty, humility, national pride and the promotion of the common good as part of the character and citizenship education provided in every school (Tan and Chin, 2004). The needs of family and community are considered more important than the needs of individuals; collectivism and a paternalistic approach is prioritised. This was given explicit focus in the 1990s with Lee Kuan Yew's 'Asian Values' platform that challenged western style political freedoms with its emphasis on the family and social harmony and the prioritisation of social over individual needs (Lee, 1998). While Confucianism is not mentioned in official character education policy, Tai and Chin (2004) believe its influence is present.

Taiwan has also preserved traditional Chinese values and has stressed the moral dimensions of education. The country has used Confucian textbooks such as Ta Hsuen (The Great Learning) which 
extends 'the Virtuous Individual' to the 'Good Citizen of the World'. Taiwan is more politically diverse with a more liberal approach, than other east Asian societies (Lee, 2004). While still influenced by Confucian values, character education has been more controversially divided between conservative and progressive camps. There are no formal timetabled lessons in moral education in schools and this has been criticised by more conservative voices. Conservative voices in Taiwan want the transmission of virtues to take place in schools, while progressives appear more concerned with the process of decision making for social justice. However, character education is expected to be taught through all subjects, through the school ethos and in extra curricula activities (Ho, Lam and Yeh, 2013). In Aristotelian terms, character develops over time as one acquires habits from parents and community, and character education in both Singapore and Taiwan certainly emphasises this.

\section{Quasi Authoritarian Character Education}

In July 2010, the CPC Central Committee and the State Council of the Peoples Republic of China convened the first National Working Conference on Education, and issued the National Outline for Medium and Long-term Education Reform and Development (2010-2020), defining the directions for the scientific development of China's educational programme. Attaching priority to the cultivation of people is the foundation of this new policy direction in which moral education is given priority. The guidelines for 'Integrating the System of Core Socialist Values into School Education' was promulgated. An important educational philosophy and principle of the National Outline for Medium and Longterm Education Reform and Development (2010-2020) is that character education will be a key part of education for each student. This would appear to promote an authoritarian character education whereby students are simply told how to act and what to believe. There are, however, contradictory components in Chinese educational practice. Wenhua College of Huazhong University of Science and Technology, has developed student-centred programmes to encourage individualised education (Fu, 2011). Hundreds of Confucian education centres and classes, and new private schools have also been established and run from the west, which indicates some diversity in approaches to character education.

However, the Chinese Communist Party has used moral education in schools to promote patriotism and socialism. In this regard, emphasis on Confucianism is at odds with recent state policy and communist ideology. The Confucian idea of character development is to cultivate virtuous behaviour in society with teachers modelling the virtues. The idea of ren is defined as 'human becoming' and teachers are expected to practice ren; that is, to care for others and promote the good of all. Character education is therefore directly related to building up society and China shares many of the classroom practices of Japanese schools, including an emphasis on extra-curricular activities. Confucian ethics is accepted as a secular moral philosophy by the Chinese government. The State therefore exploits popular support for Confucian ideas for its own social purposes (Fuqing, 1998). Confucianism is consequently seen as compatible with communism to the extent that it emphasises loyalty, self-discipline and respect for authority as well as social responsibility. As Yu (2004, p.16) says: 'the return of Confucianism does little than reinforce the collective and conservative nature of moral education shaped by communism'. However, an alternative view might be that there are two models of moral and character education existing side by side; one traditional the other socialist.

Vietnam has one of the poorest education systems in east Asia and the lowest academic standards. In Vietnam character education forms part of moral education and is provided from pre-school to tertiary levels of education. It has a strong national education policy grounded in Vietnamese law and emphasises the promotion of manners and right conduct. Character education in Vietnam reflects socialist ideology and Doan (2005) sees it as political education for nation building and instilling socialist values. Nevertheless, traditional morality is held in high public esteem and Confucian ideals are mixed with communist doctrine and celebrated in all schools. Confucianism and communism are blended to shape student behaviour in schools through prescribed rules and there is stress on the more social virtues of character (Phan, McPherron and Phan, 2011). Primary 
schools focus on character building while secondary schools give more emphasis to building the good citizen. In both Vietnam and China any criticism of the prevailing communist ideology is either ignored or condemned and communist influence continues to extend into every aspect of life. In Aristotelian terms, however, the full development of character requires open reflection and some measure of rational autonomy. Aristotle would also require full democratic participation on the part of free citizens in the political community to be virtuous - a requirement that is largely missing in communist societies. However, in Vietnam there is some variety of school provision and more private schools are being encouraged especially among the Catholic and Buddhist communities (Chu, 2008).

\section{Commentary}

There are practices in character education within east Asian countries that would be difficult to transfer to England. It is important to recognise that the very idea of east Asia is relatively modern and largely denotes a regional designation comprising many separate countries. It would be misleading to suggest a dichotomy of character educational approach between conformist east Asian countries and individualist western approaches as might be implied by my foregoing characterisation of east Asian character education as predominantly quasi collectivist, paternalistic and authoritarian. All the virtues emphasised by east Asian countries for character education are also prioritised in England, such as balance, co-operation, loyalty and self-discipline. The preamble to the 1999 National Curriculum and more recently, the nationally influential work of the Jubilee Centre for Character and Virtues in the University of Birmingham have embraced wider aims of social cohesion and cooperation emphasised in Asian cultures.

Nevertheless, if we use Geert Hofstede's (2010) research on 'Intercultural Dimensions' which considers the degree to which a society reinforces individual or collective achievements and interpersonal relationships we can see that all east Asian societies are deemed to be more collectivist in nature. In Hofstede's measurement, England scores highly for individualism which implies that individual rights are dominant within a loosely-knit social framework, while all the east Asian societies score considerably lower implying a more collectivist focus and tightly-knit framework to these societies. Hofstede's scores appear to reinforce the view that east Asian societies have a greater sense of their self-image as 'We' as opposed to the 'I' of England. The implication for character education policies may be that they are culturally constructed from local communities in east Asia. Nonetheless, this polarisation of cultures between a west-individual view and an east - collective view within an increasingly globalised context requires greater empirical evidence than what is offered by Hofstede if it is to be sustained.

One should also not confuse moral education in east Asian countries with social conformity or non-questioning loyalty to the state, insofar as values promoted by the state in these countries are not uncritically accepted by everyone. The national traditions of such countries are indeed strong and patriotism is often stressed in school textbooks (Meyer 1988, p.1130), but this is largely taught indirectly through celebrated national literature, much as Shakespeare and other national classics are taught in the west. Generally, moral virtues are considered more important in these countries than civic virtues. The general social conservatism of such countries and the overwhelming emphasis on the group over the individual are idealistic political aspirations, but in practice this goal is not always successfully achieved. These governments are able to state clear goals because they are largely free of the controversies that rage over moral and character education in liberal-democratic societies. East Asian governments range from quasi collectivist and paternalist approaches to character education to quasi-authoritarian and even authoritarian approaches than a democratic government in England could allow. Such east Asian societies were previously marked by a uniform authoritarianism which emphasised patriotic education, conformity to strict codes of conduct, and nationalism. In all of these societies schooling was directed towards achieving national identity and cohesion, whilst character building was directed to defence from possible attack, particularly in South Korea and Taiwan. While political education was at the forefront, new teaching approaches, a concern 
for critical thinking and some focus on civic values are not entirely absent in these countries. Still, while there has been a cultural shift in some places that focuses on individualism, this is a minority position, albeit a growing one.

Confucian traditions and the Confucian concern for character education are still strong in some east Asia countries and are often mixed with Buddhist, Taoist and other values. Such blends of traditional ideas are largely spread by individuals and families from one generation to the next (see Tu Wei-Ming, 1996). Character education policies are therefore sometimes underpinned by the teachings of Confucius, especially in relation to social welfare. Individualist trends can be discouraged and the collective prioritised. Extra curricula activity is hugely important in east Asian societies as part of socialisation and character building and some of this has been borrowed or copied from Britain's public schools of the nineteenth century. There are numerous direct and indirect ways that character building takes place in east Asian schools that might be recognised and accepted as good practice in England, but some of these practices, such as consuming teacher time after school clubs, may come at too high a price for western teachers.

England is more cautious about asserting character qualities for schools while east Asian countries are often forthright in asserting a strong role for the state. East Asian societies emphasise the commitment to national identity while England is again perhaps less assertive in this. East Asian societies also tend to have a stronger common tradition than more pluralistic societies such as England. As Cummings (1989, p.180) say 'Asian states appear less constrained by law and custom in their review of policy options....In contrast Western states tend to focus on a relatively narrow scope of values and mobilize fewer options for their realization'. It is interesting that in east Asian countries goals of resilience and grit - very much seen as American influences and increasingly influential in English policy rhetoric - are less evident; but there is something similar in the form of 'guts' or perseverance (ganbari) which is pervasively within and beyond schooling. But emphasis is placed on moral and intellectual virtues no less than performance virtues with one of the most common Japanese phrases being garbatte kudasai, meaning 'please persevere or do your best'. Character and moral education is not part of the examination system and yet examinations are the mainstay of Asian school systems leading to some tension with ideals of co-operation. There also appears to be a difference in that east Asian societies value group harmony while England encourages individual development and choice. However, the promotion of rational autonomy is not entirely absent in east Asian societies.

Some in east Asia countries have historically viewed England as hedonistic, weak-willed and as a place that embraces excessive human rights at the expense of social cohesion (see Gopinathan 1988, p.133). While Gopinathan exaggerates this feature of English education, England does pay much more attention to individual rights. Values in east Asian character education are largely based on traditional practices and are prescribed by governments. However, there is not sufficient evidence to conclude that east Asian youth are less selfish and better at working for the common good of society than more liberally educated English youth. There is a general impression in the west that east Asian societies are more stable, more orderly, respect the family and work together. But such societies are much influenced by ideas from England and the US (Su, 2008 and Fuqing, 1998). Cummings (1989) has exposed many myths generated about east Asian education systems. Ke and Fang (2004), Chinese scholars working in Chinese Universities, have argued that the main Chinese objectives for character education ought to be about recognising and respecting individuality, but it is not clear that this could become a reality in a communist society. In any case, concepts such as 'individuality' in east Asian societies can be ambiguous and there is some debate in these societies between conservatives and progressives about whether to emphasise more patriotism or more creativity in the young. Parental beliefs and attitudes are also key to understanding both academic attainment and character building in many east Asian societies; lessons from the schools' systems in east Asia alone would not therefore be suffice to improve English schools as widespread cultural change would be required among parents in England to value education (see Jerrim, 2014). 
Many east Asian states are quasi paternalistic about character education; regarding it as justifiable to interfere in the lives of students because they will in the end be better off as a result. However, English schools can also be quasi authoritarian institutions with pronounced paternalistic elements in promoting and protecting what they perceive as the well-being of students. English policies on reducing poverty, welfare dependency, supervising the poor, and racial integration can all be paternalistic and intrude upon the freedom of individuals. English schools also enforce existing parental values or seek to change lifestyles on the grounds that many students lack educationally required family support and cultural capital.

An important tension in the idea of character education concerns whether it is simply a culture free phenomenon that provides us with universal traits and dispositions to be applied in any context or is it culturally constructed from the beliefs and practices of a particular local community. Is it to be viewed as part of a continuum between conservative and progressive approaches?

\section{Conclusion}

Still the goals of character education in England are not as clear as those officially stipulated in east Asian countries. There is also a degree of convergence in policy goals in and between east Asian countries. By comparison, English policy goals for character education are not as well developed and there is some gap between government policy announcements and the reality of school practices - although this may be changing. Character education is a policy that because of the dynamism of educational change and the interaction among various agencies at different levels of the school system often means that policy goals are compromised in reality. By contrast east Asian governments dictate clear and ambitious goals that serve to reinforce character education, and supporting it with resources and training programmes to ensure more effective implementation than in England. Such governments usually frame policies through long and detailed consultations with teachers, academics and civil servants. The extent to which English schools stress individuality and freedom may also be exaggerated insofar as there is considerable stress on discipline and order as well as on working with others. England might therefore benefit from a study of character education practices in east Asia so long as we recognise that the cultural experience of character education provision in east Asian countries is not adaptable wholesale outside the home context. Borrowing in both directions may be possible, though this will always require some adaptation, but learning from others is more effective than policy borrowing.

\section{References}

Arthur, J. (2003). Education with Character: The moral economy of schooling. London: Routledge.

Arthur, J. (2005). The re-emergence of character education in British education policy. British Journal of Educational Studies, 53(3), pp. 239-254.

Barber, M. (Ed.) (2012).Oceans of Innovation: The atlantic, the pacific, global leadership and the future of education. London: Institute of Public Policy Research.

Brandt, R. (1992).Morality, Utilitarianism and Rights. Cambridge: Cambridge University Press.

Broadie, S. and Rowe, C. (2002). Aristotle's Nicoachean Ethics: Translation, introduction, and commentary. Oxford: Oxford University Press.

Cave, P. (2001). Educational reform in Japan in the 1990s: 'Individuality' and other uncertainties. Comparative Education,37(2), pp. 173-191.

Cave, P. (2004). Bukatsudo: The educational role of Japanese school clubs. Journal of Japanese Studies,30(2), pp. 383-415.

Cave, P. (2007). Primary Schools in Japan. Abingdon: Routledge.

Cen, G. and Jun Y. (2014).Traditional Chinese philosophies and their perspectives on moral education. In L. Nucci, D. Narvaez and T. Krettenauer (Eds.), The Handbook of Moral and Character Education. New York: Routledge, pp. 30-42. 
Chou, M.J. ,Tu, Y.C. and Huang, K.P. (2013). Confucianism and character education: A Chinese view. Journal of Social Science, 9(2), pp. 59-66.

Chu, L. T. (2008).Catholicism vs communism, continued: The Catholic church in Vietnam. Journal of Vietnamese Studies, 3(1), pp. 151-192.

Cummings, W. (1989). The American perceptions of Japanese education. Comparative Education, 25(3), pp. 293-302.

Cummings, W., Gopinthathan, S. and Tomoda, Y. (Eds.) (1988).The Revival of Values Education in Asia and the West. New York: Pergamon Press.

Doan, D. H. (2005). Moral education or political education in the Vietnamese educational system. Journal of Moral Education, 34(4), pp. 451-463.

Doris, J. (2002). Lack of Character: Personality and moral behaviour. Cambridge: Cambridge University Press.

Fu, K. (2011). Character education: Concepts, practice and reflection: 2011 summary of the International conference on the character education. Journal of the Chinese Society of Education,10, pp. 9-11.

Fuqing, Z. (1998). The Strategy for Implementing Character Education. Qingdao: Qingdao Ocean Press.

Gopinathan, S. (1988). Being and becoming: Education for values in Singapore. In W. Cummings, S. Gopinathan and Y. Tomoda (Eds.), The Revival of Values Education in Asia and the West. New York: Pergamon Press, pp. 131-145.

Green, A. (2000). Converging paths or ships passing in the night? An English critique of Japanese school reform. Comparative Education,36(4), pp. 417-436.

Ho, H.Z., Lam, Y.W. and Yeh, K.H. (2013). Character education in Taiwan: A reflection of historical shifts in sociocultural contexts. Childhood Education, 89(6), pp. 362-367.

Hofstede, G., Hofstede, J. and Minkov, M. (2010).Cultures and organisations: Software of the mind. New York: McGraw-Hill.

Hunter, J.D. (2001).The Death of Character: Moral education in an age without good or evil. New York: Basic Books.

Jansen, M. (1957). Values and politics in Japan. Foreign Affairs, 35(4), pp.666-678.

Jerrim, J. (2014).Why do East Asian children perform so well in PISA? An investigation of Westernborn children of East Asian descent. Working paper. London: Institute of Education, University of London.

Jeynes, W. (2008). What we should learn and should not learn from the Japanese and other Asian education systems. Educational Policy, 22(6), pp. 900-927.

Kam, H.W. and Gopinathan, S. (1999). Recent developments in education in Singapore. School Effectiveness and School Improvement: An International Journal of Research, Policy and Practice, 10(1), pp. 99-117.

Ke, W. and Fang, X. (2004). On the construction of character education system in universities in China. Journal of Higher Education,10, pp.26-28.

Kristjánsson, K. (2015). Aristotelian Character Education. London: Routledge.

Lee, C. H. (2004). Changes and challenges for moral education in Taiwan. Journal of Moral Education,33(4), pp. 573-595.

Lee, G. L. (2013). Re-emphasizing character education in early childhood programs: Korean children's experiences. Childhood Education, 89(5), pp. 315-322.

Lee, I.J. (2001). The proper direction and practical ways for character education in Korean elementary schools. Asia Pacific Educational Review, 2(2), pp. 72-83.

Lee, K.W. (1998). The Singapore Story: Memoirs of Lee Kuan Yew, Singapore: Singapore Press Holdings. Lord, C. (2013). Aristotle's Politics. Chicago: University of Chicago Press.

Luhmer, K. (1990). Moral education in Japan. Journal of Moral Education, 19(3), pp. 172-182.

McIntyre, A. (1967). A Short History of Ethics. London: Routledge.

McIntyre, A. (1999). How to seem virtuous without actually being so. In J. M. Halstead and T.H. McLoughlin (Eds.), Education and Morality. London: Routledge, pp. 118-131. 
McIntyre, A. (2013). How Aristotelianism can become revolutionary: Ethics, resistance and utopia. In P. Blackledge and K. Knight (Eds.), Virtue and Politics: Alasdair MacIntyre's Revolutionary Aristotelianism. Indiana: University of Notre Dame Press, pp. 11-19.

Meyer, J. F. (1988). A subtle and silent transformation: Moral education in Taiwan and the people's republic of China. In W. Cummings, S. Gopinathan and Y. Tomoda (Eds.), The Revival of Values Education in Asia and the West. New York: Pergamon Press, pp. 109-130.

Otsu, K. (2000).Civics education in Japan: Values promoted in the school curriculum. Asia Pacific Journal of Education, 20(1), pp. 53-62.

Phan, L.H., McPherron, P. and Phan, V.Q. (2011). English language teachers as moral guides in Vietnam and China. In J. Ryan (Ed.), Education Reform in China. Abingdon: Routledge, pp. 132-158.

Ryan, K., Lerrner, B., Bohlin, K., Nakayama, O., Mitzuno, S. and Horiuchi, K. (2011).Happiness and Virtue: Beyond east and west. Tokyo: Tuttle.

Shields, J. (1998). The society for Japanese studies. The Journal of Japanese Studies, 24(1), pp. 132-136.

Starr, D. (2012). China and the Confucian Education Model. Teaching and Learning Universitas 21 Position Paper. Durham: University of Durham.

Su, B. (2008). A comparison and research on the Sino-US character education. Asia Social Science, 4(10), pp. 111-115.

Suh, S. (1988). Ideologies in Korea's morals and social studies texts: A content analysis. In W. Cummings, S. Gopinathan and Y. Tomoda (Eds.), The Revival of Values Education in Asia and the West. New York: Pergamon Press, pp. 93-108.

Takayama, K., and Apple, M.W. (2008).The cultural politics of borrowing: Japan, Britain and the narrative of educational crisis. British Journal of Sociology of Education, 29(3), pp. 289-301.

Tan, C. and Tan, S. C. (2014). Fostering social cohesion and cultural sustainability: Character and citizenship education in Singapore. Diaspora, Indigenous, and Minority Education: Studies of Migration, Integration, Equity, and Cultural Survival,8(4), pp. 191-206.

Tan, T.W. and Chin, C.L. (2004). Moral and citizenship education as statecraft in Singapore: A curriculum critique. Journal of Moral Education, 33(4), pp. 597-606.

The Japanese Times Editorials 'Moral Education Raises Risks', 10

The Japanese Times Editorials 'Moral Education's Slippery Slope', 24 ${ }^{\text {th }}$ October 2014.

Traiger, J. (1996). Lessons from the Japanese: Adapt don't adopt. Education, 116(3), pp. 441.

Tu, W.M. (1996).Confucian Tradition in East Asian Modernity. Cambridge: Harvard University Press. Yu, T. (2004). In the Name of Morality. New York: Peter Lang. 
